\title{
COMMENT
}

\section{MINORITY RIGHTS AND THE CORPORATE "SQUEEZE" AND "FREEZE"}

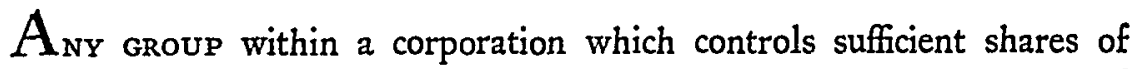
stock to elect a majority of the directors and to dictate the outcome of stockholders' votes in other instances has, through the use of a variety of devices, the power unconscionably to benefit its members at the expense of the minority stockholders. For example, a shareholder or group of shareholders may be deprived of any voice in the making of corporate decisions, or even be forced completely out of the corporation. In like manner, one class of stock may successfully pursue plans tailored to serve its ends at the expense of other classes. A majority thus bent on applying a corporate "squeeze" or "freeze" is immeasurably aided by traditional judicial reluctance to interfere in corporate affairs. ${ }^{1}$ Moreover, many stockholders not only are unaware of the protections given them by law against unfair treatment, but, having only slight knowledge of the intricacies of corporate mechanics, often do not recognize the harmful potential of certain policies until it is too late-especially when management fails to make adequate reports to stockholders. These factors combine to make the position of the minority stockholder in some corporations, notably the close corporation, an insecure and financially dangerous one.

In an attempt to shield minority stockholders from some of the more flagrant abuses at the hands of the majority, the courts have verbalized in vague terms the situations in which judicial interference with corporate activities may be expected. Most courts recognize, to some extent at least, that majority stockholders owe to minority interests some sort of a fiduciary duty. ${ }^{2}$ Yet, these courts are disposed to aid the

\footnotetext{
${ }^{1}$ See Ballantine, CoRporations $\$ \$ 278,285,295$ (rev. ed. 1946) [hereinafter cited as BALLANTINE].

3 "The same considerations of fundamental justice which impose a fiduciary character upon the relationship of the directors to the stockholders will also impose, in a proper case, a like character upon the relationship which the majority of the stockholders bear to the minority. When, in the conduct of the corporate business, a majority of the voting power in the corporation join hands in imposing its policy upon all, it is beyond all reason and contrary, it seems to me, to the plainest dictates of what is just and right, to take any view other than that they are to be regarded as having placed upon themselves the same sort of fiduciary character which the law impresses upon the
} 
minority only when acts of the majority can be characterized as abusive of discretion, ${ }^{3}$ unreasonable or arbitrary, ${ }^{4}$ in bad faith, ${ }^{5}$ or fraudulent. ${ }^{6}$ These somewhat amorphous standards, combined with the fact that the burden of proof rests on the complainant, ${ }^{7}$ make the minority stockholder's position in court difficult. About all that can be said in a general way is that while there is unquestionably a legitimate sphere in which the majority, by virtue of its position, can act in its own interest, even if the minority suffers, there is at least a subjective line beyond which the majority cannot transgress without risking judicial sanction.

Minority stockholders also have the theoretical benefit of statutory and charter safeguards which purport to protect their interests against the power of the majority, the most prominent examples of which are provisions for class and cumulative voting and high vote requirements for certain fundamental changes. Even so, the power commanded by those in control of a corporation is usually sufficiently overwhelming to insure successful pursuit of most indicated courses of action.

\section{Dividend Withholding and High Salaries}

The declaration of dividends is traditionally regarded as a matter within the sole discretion of the board of directors. ${ }^{8}$ Therefore, with control of the board of directors, the majority can insure that surpluses remain in the corporate treasury and can cause annual profits, which might otherwise be used to pay dividends, to be added to reserve or surplus accounts. ${ }^{\circ}$ When majority shareholders also occupy managerial positions, they can make the squeeze particularly effective by siphoning off profits in the form of larger salaries for themselves, for, within vague

directors in their relation to all the stockholders. ... Unless the majority in such a case are to be regarded as owing a duty to the minority such as is owed by the directors to all, then the minority are in a situation which exposes them to the grossest frauds and subjects them to most outrageous wrongs." Allied Chem. \& Dye Corp. v. Steel \& Tube Co. of America, 14 Del. Ch. 1, 12-13, 120 Atl. 486, 49 I (1923).

${ }^{8}$ Jones v. Motor Sales Co., 322 Pa. 492, I 85 Atl. 809 (1936).

- Channon v. Channon Co., 218 Ill. App. 397 (1920).

'Stevens v. United States Steel Corp., 68 N.J. Eq. 373, 59 Atl. 905 (Ch. I905); Tefft v. Schaefer, 136 Wash. 302, 239 Pac. 837 (1925).

Mobile Towing \& Wrecking Co. v. Hartwell, 208 Ala. 420, 95 So. 191 (1922).

'Waldrop v. Martin, 237 Ala. 556, I88 So. 59 (1939); Allaun v. Consolidated Oil Co., I6 Del. Ch. 318, 147 Atl. 257 (1929); Robinson v. Pittsburgh Oil Refining Corp., I4 Del. Ch. 193, 126 Atl. 46 (I924).

Ballantine \$ 42 .

'See Casson v. Bosman, 137 N.J. Eq. 532, 45 A.2d 807 (Ct. Err. \& App. 1 946); Jones v. Motor Sales Co., 322 Pa. 492, I 85 Atl. 809 (1936). See Generally, Frey, The Distribution of Corporate Dividends, 89 U. PA. L. REv. 735 (194I). 
limits, the determination of compensation is likewise a matter left entirely to the discretion of directors. ${ }^{10}$ Such corporate policies have a natural tendency to lower the market value of the stock, which, in turn, may pressure the minority to sell its shares to the majority at less than their actual worth. The possible denouement is that the majority ultimately may acquire complete ownership of the corporation at an unfairly low price, thereby depriving the minority of much of its original investment, as well as the opportunity to participate in a going concern.

In determining whether the corporate majority has acted properly in withholding dividends, the courts have emphasized several factors. Prominent among these is the corporation's business needs. ${ }^{11}$ Although it is difficult to find a case where relief was granted solely because the business did not need additional capital, consideration of this factor in practically every judicial opinion involving dividend withholding attests its importance. ${ }^{12}$ Where the corporation has needed large amounts of working or expansion capital, sustained retention of funds has been upheld. ${ }^{13}$ On the other hand, when it has appeared, along with other factors indicating majority abuse, that profits have been witheld wholly out of proportion to the needs of the business, courts have forced a dividend payment. ${ }^{14}$ Among the criteria employed to dispose of cases falling

${ }^{10}$ "The discretion of the directors as to the proper amount of compensation for executive officers is wide, but it may be judicially reviewed and does not extend to wasteful diversion of income, leaving no fair return to the shareholders." BaLlentrine $§ 231$, at 552. See Washington, The Corporation Executive's Living Wage, 54 HARv. L. REv. $733,756,770$ (194r).

${ }_{12}$ See Thomas v. Matthews, 94 Ohio St. 32, 113 N.E. 669 (1916), where the court said that the directors were to consider the needs of the business, the sums necessary for its operation until income from further operations was available, the amount of its debts and whether they should be paid, and the character of its surplus assets, whether cash, credits, or merchandise. Another court has said that whether dividends should be paid "depends usually on several considerations, is a relative question, not always susceptible of clear demonstration, and is a matter, to a considerable extent, of good judgment in conducting the company's business, and of good faith in upholding its contracts on the part of directors." Hazeltine v. Belfast \& M.H.L. R.R., 79 Me. 411, 10 Atl. 328, 330 (1887). See also, Hayes v. St. Louis Union Trust Co., 317 Mo. 1028, 298 S.W. $91(1927)$.

${ }^{13}$ See cases in note 11 supra.

${ }^{13}$ See Raynolds v. Diamond Mills Paper Co., 69 N.J. Eq. 299, 60 Atl. 941 (Ch. 1905); Gesell v. Tomahawk Land Co., 184, Wis. 537, 200 N.W. 550 (1924). Ballantine argues that expansion capital should be raised at least partly by new financing rather than by withholding dividends on the preferred shares, particularly where common shareholders are controlling the coporation. BALLANTINE $\$ 232$, at 555 .

${ }^{14}$ See Crichton v. Webb Press Co., $11_{3}$ La. 167,36 So. 926 (1904), where the court forced the declaration of a dividend because, among other reasons, the corporation had made profits of over yo times the amount of original capitalization. See also 
between the two extremes are: the amount of working capital required in prior years; an estimate of future business prospects; the size of any existing surpluses; an estimate of the cost of any proposed expansion; and a consideration of the liabilities to which the corporation is, or reasonably may be, subject in the near future. The utilization of such criteria to show retention of funds beyond reasonable need, however, is made exceedingly difficult by the complexities of modern business and the current expanding nature of our economy. ${ }^{15}$ Conceivably, a court might order payment of a dividend in spite of a need for more capital, thus compelling the management to raise funds from other sources; but this would, indeed, be unlikely.

Evidence of a conflict of interests between the members of the majority and the minority has also been deemed significant in dividend withholding cases. One court acceded to the minority's request upon a showing that the majority was withholding dividends solely to obtain personal tax advantages. ${ }^{16}$ Relief was also granted where it was proved that dividends were withheld so that corporate debts, incurred to the majority in self-dealing contracts, could be satisfied. ${ }^{17}$ Similarly, evidence of outright hostility toward the minority or of an intent to drive the minority out of the corporation bears directly on the issue of conflict of interest. ${ }^{18}$ In sum, any evidence that the majority has deliberately exploited its power unreasonably to further selfish ends at the expense of

Hiscock v. Lacy, 9 Misc. 578, 30 N.Y. Supp. 860 (Sup. Ct. I894). For a recent treatment of this problem, see the comparative law note in I959 DUKE L.J. 116, 122.

${ }^{16}$ In one case the court pointed out that virtually all industry in the United States had been expanding over the preceding 20 years. There was also evidence that in the absence of capital expansion the company would have had to reduce its business activity because of its inability to meet all of its orders. These and other factors led the court to conclude that the expansion was justified. Raynolds v. Diamond Mills Paper Co., 69 N.J. Eq. 299, 60 Atl. 941 (Ch. 1905).

${ }^{18}$ Whittemore v. Continental Mills, 98 F. Supp. ${ }_{387}$ (D. Me. 1951). The court was also influenced by the fact that extended expansion of the surplus might possibly have subjected the corporation to a tax penalty.

A variation on the situation in the Whittemore case could occur where the majority of the shares of a corporation are held by another corporation and a minority of the shares are held by individuals in high income tax brackets. Should the owning corporation wish to pressure the minority stockholders into selling their shares, they could threaten to declare a very large dividend. Such a dividend would operate to the detriment of the minority, since they would pay heavy income taxes on the dividend, while the owning corporation would pay a maximum tax of $7.8 \%$ by virtue of the favorable treatment accorded inter-corporate dividends. Cf. INT. REV. CODE OF $1954 \S 243$.

${ }^{17}$ Crichton v. Webb Press Co., 113 La. 167, 36 So. 926 (1904).

${ }^{28}$ Flemming v. Heffner \& Fleming, 263 Mich. 561, 248 N.W. 900 (1933). 
the minority will greatly increase the complainant's chance of success in court. ${ }^{19}$

With regard to salaries, it should be noted that courts generally are more receptive to complaints of unjustified compensation when the management is comprised of those who also control the selection of the board of directors. ${ }^{20}$ Several tests have been employed to measure the reasonableness of remuneration for such stockholders holding management positions. ${ }^{21}$ Salaries are sometimes compared with those paid to executives of other corporations engaged in the same type of business. ${ }^{22}$ Compensation previously paid to the executive or his predecessor may be examined, ${ }^{23}$ and if there has been a substantial increase, a court might make further inquiry to determine whether there has been a proportionate increase in duties and responsibilities ${ }^{24}$ or in corporate earnings. ${ }^{25}$ The salaries of members of the controlling group have also been compared with those of other employees of the same corporation, due regard being given to job differences. ${ }^{26}$

Once the protesting stockholder has convinced a court that it should

\footnotetext{
${ }^{10}$ Cases are collected in Annot., 55 A.L.R. 8, 44, 133 (1928); Annot., 76 A.L.R. 885,888 (1932).

${ }^{20}$ See Seitz v. Union Brass \& Metal Mfg. Co., 152 Minn. 460,189 N.W. 586 (1922); Mortimer v. D. T. McKeithan Lumber Corp., 127 S.C. 266, 120 S.E. 723 (1923).

${ }^{21}$ See generally, Washington \& Rothschild, Compensating the Corporate EXECUTIVE, ch. 13 (rev. ed. 1951).

${ }^{22}$ Church v. Harnit, 35 F.2d 499 (6th Cir. 1929), cert. denied, 281 U.S. 732 (1930); Backus v. Finkelstein, 23 F.2d 531 (D. Minn. 1924), appeal dismissed, 31 F.2d roII (8th Cir. 1929); Stratis v. Andreson, 254 Mass. 536, 150 N.E. 832 (1926).

${ }^{23}$ Barrows v. J. N. Fauver Co., 280 Mich. 553,274 N.W. 325 (1937); Luyckx v. R. L. Aylward Coal Co., 270 Mich. 468, 259 N.W. 135 (1935); Lillard v. Oil, Paint, \& Drug Co., 70 N.J. Eq. 197, 56 Atl. 254 (Ch. 1903); Raynolds v. Diamond Mills Paper Co., 69 N.J. Eq. 299, 60 Atl. 941 (Ch. 1905).

${ }^{24}$ See Raynolds v. Diamond Mills Paper Co., supra note 23, where increases in salaries for the president and secretary, from $\$ 12,000$ to $\$ 15,000$, and from $\$ 6,000$ to $\$ 9,000$, were held to be unreasonable, one reason being that there was no corresponding increase in their duties.

${ }^{25}$ Francis v. Brigham-Hopkins Co., $108 \mathrm{Md}$. 233, 70 Atl. 95 (1908); Esposito v. Riverside Sand \& Gravel Co., 287 Mass. 185 , 191 N.E. 363 (1934); Seitz v. Union Brass \& Metal Mfg. Co., 152 Minn. 460, 189 N.W. 586 (r922). See Costello v. Thomas Cusack Co., 96 N.J. Eq. 95, 124 Atl. 620 (Ch. 1924), where the president was voted a salary of $\$ 50,000$, an allowance of $\$ 10,000$ for expenses, and a bonus of $10 \%$ of the profits. It was held that this was not shown to be unreasonable because business had increased from $\$ 2,000,000$ to $\$ 4,000,000$ each year.

${ }^{20}$ Backus v. Finkelstein, 23 F.2d $53 \times$ (D. Minn. 1924), appeal dismissed, 31 F.2d Ior1 (8th Cir. 1929); Davids v. Davids, 135 App. Div. 206, 120 N.Y. Supp. 350 (1909).
} 
thus intervene in the affairs of the corporation, ${ }^{27}$ several remedies are available. One who has sold his stock at a sacrifice solely because dividends have been withheld may be allowed to recover the difference between the sale price and the actual worth of his stock. ${ }^{28} \mathrm{~A}$ court of equity can, of course, compel payment of a dividend, and one court went so far as to retain jurisdiction over a case for five years to insure continuing good faith compliance with such an order. ${ }^{29}$ Courts also have occasionally placed even prosperous corporations in receivership where no other adequate remedy was available. ${ }^{30}$ In North Carolina, a novel statutory provision gives twenty per cent of the stockholders the right to compel a dividend declaration of at least one-third of the current profits. ${ }^{31}$ Finally, a court has the power to adjust any unreasonable compensation. ${ }^{32}$

\section{Merger}

A corporate merger (or consolidation) can also be used to freeze out the minority stockholders or to alter the rights and preferences of their share contract. ${ }^{33}$ It is well established that, in exchange for their original shares, stockholders of an absorbed corporation may be given stock of the surviving corporation with markedly different rights and preferences, ${ }^{34}$ the justification being that one who buys stock in a corpora-

\footnotetext{
${ }^{27}$ It should be emphasized again at this point that the courts are reluctant to impose their judgment upon the directors' discretion in the declaration of dividends. See Dodge v. Ford Motor Co., 204 Mich. 459, 170 N.W. 668 (1919); Connelly v. Weisfeld, 142 N.J. Eq. 406, 59 A.2d 869 (Ct. Err. \& App. 1948); Note, 64 Harv. L. REv. 299 (1950).

${ }^{28}$ Von Au v. Magenheimer, I26 App. Div. 257, I 10 N.Y. Supp. 629 (1908).

${ }^{29}$ Patton v. Nicholas, 154 Tex. 385,279 S.W.2d 848 (1955).

${ }^{39}$ Tower Hill-Connellsville Coke Co. v. Piedmont Coal Co., 64 F.2d 817 (4th Cir. 1933).

${ }^{31}$ N.C. GEN. STAT. $\$ 55-50$ (i) (Supp. 1957). $\quad{ }^{30}$ See cases in footnote 25 supra.

${ }^{33}$ See generally, 15 Fletcher, Private Corporations $\$ 7159$ (perm. ed. rev. repl. 1938) [hereinafter cited as FLETCHER]; 19 C.J.S., Corps. $\$ 1612$ (1940); Fuld, Some Practical Aspects of A Merger, 60 HARV. L. ReV. 1092 (1947); Lattin, Remedies of Dissenting Stockholders Under Appraisal Statutes, 45 HARV. L. REv. 233 (1931); Comment, 45 YALE L.J. I05 (1935).

${ }^{34}$ See Hottenstein v. York Ice Machinery Corp., 45 F. Supp. 436 (D. Del. 1942), aff'd, 136 F.2d 944 (3d Cir. 1943); Windhurst v. Central Leather Co., 105 N.J. Eq. 621, 149 Atl. 36 (Ch. 1930); Adams v. United States Distributing Corp., 184 Va. 134, 34 S.E.2d 244, cert. denied, 327 U.S. 788 (1945).

It has been held that a provision in a stock certificate providiug that a merger shall not impair the rights and preferences of the stock is invalid when it conflicts with a statute which permits merger agreements that include changes in the rights and preferences of stock. It is argued that such a statutory provision is evidence that it was never intended that rights and preferences should not be altered in a merger. See Clarke v. Gold Dust Corp., ro6 F.2d 598 (3d Cir.), cert. denied, 309 U.S. 671 (1939).
} 
tion understands that his rights and preferences may be altered by the action of a majority of shareholders. ${ }^{35}$

The case of Matteson v. Ziebarth ${ }^{36}$ illustrates the devastating fashion in which a merger may be used either to oust the minority stockholder or to deprive him of his role in the management of the corporation. A minority stockholder, invoking the common law rule, blocked a proposed sale of all of the corporation's outstanding stock by refusing to consent to the transaction. ${ }^{37}$ The majority stockholders then organized a dummy corporation, purchased all of its outstanding common stock, and made themselves its directors. Shortly thereafter, by a two-thirds vote, the stockholders of the original corporation approved a merger with the dummy corporation under the terms of which each share of common stock in the original corporation was to be exchanged for one share of redeemable preferred stock of the dummy corporation, the apparent intention being to redeem the stock of the dissenter. In sustaining the merger against allegations of fraud and unfairness, the court relied on the fact that the transaction was for a lawful business purpose. Moreover, the court felt that the dissenting shareholder was not actually injured by the merger, since he had a right to have his shares appraised and purchased by the corporation.

As demonstrated in Federal United Corporation v. Havender, ${ }^{38}$ merger can also be a potent device for erasing dividend arrearages, especially when this effect cannot be achieved by charter amendment. ${ }^{30}$

${ }^{35}$ See Federal United Corp. v. Havender, 24 Del. Ch. 318, 11 A.2d 331 (Sup. Ct. 1940), 25 WASH. U.L.Q. 614.

${ }_{36} 40$ Wash. 286, 242 P.2d 1025 (1952).

${ }^{37}$ The Ziebarth Corporation was in failing circumstances. An agreement was made with a larger corporation whereby it agreed to purchase all the outstanding Ziebarth stock in exchange for its own stock. The dissenter objected to the plan because it called for the purchasing corporation to hire the majority stockholder at a salary of $\$ 26,000$ for 8 months. The dissenting stockholder contended that part of this salary was in consideration for the agreement to sell the stock. He argued that all of the stockholders should share in this money and refused to consent to the plan. See also Outwater v. Public Service Corp., 103 N.J. Eq. 461, 143 Atl. 729 (Ch. 1928).

${ }_{38} 24$ Del. Ch. 3 I8, II A.2d 331 (Sup. Ct. 1940), 25 WASH. U.L.Q. 614.

${ }^{30}$ See Ballantine $\$ 296$. In Hottenstein v. York Ice Mach. Corp., 45 F. Supp. 436 (D. Del. x 942), aff'd, 136 F.2d 944 (3d Cir. 1943), the court upheld the elimination of accrued dividends by a merger with a wholly owned subsidiary which was created for that purpose.

Thus, the holders of preferred shares with large dividend arrearages may find that the result of the merger is to wipe out their arrearages and make possible the payment of a dividend on the common stock from that future surplus from which they had expected to draw their arrearages. See generally, Porges v. Vadsco Sales Corp., 27 Del. Ch. 127, 32 A.2d r48 (Ch. r9+3); Donohue v. Heuser, 239 S.W.zd 238 (Ky. 
There, the plaintiffs brought a bill in equity to declare void a proposed merger of the defendant corporation with its wholly-owned subsidiary, where the result would have been the elimination of accrued dividends on the plaintiffs' stock. The merger was upheld on the ground that the elimination of accrued dividends lay within the power of the corpora$\operatorname{tion}^{40}$ and on the reasoning that one who buys stock in a corporation "must be held to know that dividends may accumulate on a preferred stock, and that in the event of a merger of the corporation issuing the stock with another corporation, the various rights of shareholders, including the rights to dividends on preference stock accrued but unpaid, may, and perhaps must, be the subject of reconcilement and adjustment. ... \$41 The court also alluded to and may have been influenced by the fact that the dissenting shareholder had the alternative of invoking an appraisal statute.

Modern corporation statutes, by facilitating fundamental corporate changes, such as merger, have, incidentally, made it easier to victimize minority interests. In mitigation of this danger, at least forty-two states have adopted appraisal statutes designed to give some measure of protection to minority shareholders. ${ }^{42}$ Theoretically, these statutes enable 1951) ; Dratz v. Occidental Hotel Co., 325 Mich. 699, 39 N.W.2d 341 (1949); Annot., 8 A.L.R.2d 893 (1949); Becht, Alterations of Accrued Dividends, 49 Mich. L. REv. 363, 565 (1951); Comment, 47 Mich. L. Rev. 81 (1948); Note, 57 Harv. L. Rev. 894 ( 1944 ).

"To The court said: "The state has an interest in the corporate structures under its authority. Having provided for the merger of corporations, they are not regarded with disfavor. On the contrary, mergers are encouraged to the extent that they tend to conserve and promote corporate interests. . . . Moreover, it is recognized that there may be shareholders who will be dissatisfied with the effect of the terms of the merger proposal upon the rights attached to their shares. While their right to dissent is admitted, the public policy of the state declared by the statute, somewhat analogous to the right of eminent domain, does not permit a dissenting shareholder, as against an affirmative vote of two-thirds, to veto a merger agreement if its terms are fair and equitable in the circumstances of the case. . . . The broad contention advanced by the appellees, that the merger provisions of the General Corporation Law do not authorize the extinguishment of dividends accumulated on preference stock, even if the terms of the merger proposal are fair and equitable, must be denied. . ." Federal United Corp. v. Havender, 24 Del. Ch. 318, 334-35, I I A.2d 331, 338-39 (Sup. Ct. 1940), 25 WAsh. U. L. Q. 614.

"Id. at 334 , I I A.2d at $33^{8}$.

'With the virtual disappearance of 'vested rights,' and the almost limitless presentday scope of charter amendment, a shareholder holds that bundle of rights that we call his shares virtually at sufferance; votes of others may transform that bundle into one utterly, perhaps shockingly, different." Latty, Some Miscellaneous Novelties in the New Corporation Statutes, 23 LAW \& Contemp. ProB. 363,387 (1958).

${ }^{13}$ See Chicago Corp. v. Munds, I2 Del. Ch. 142, 172 Atl. 452 (Ch. 1934), I 9 
a stockholder who dissents from certain corporate actions to have his stock appraised at a fair value and purchased by the corporation. ${ }^{43}$ In most jurisdictions this remedy is not exclusive; ${ }^{44}$ the dissenter may persuade the court to enjoin or set aside the merger if he can prove that the particular merger was illegal ${ }^{45}$ or that it amounted to fraud..$^{48}$ In some states, however, the appraisal remedy is exclusive; ${ }^{47}$ the dissenting shareholder must acquiesce in the proposed merger or accept the appraised value of his stock, although it is well known that appraisals sometimes fail to reflect the true worth of stock. The desirability of the theory of nonexclusiveness is indicated by the fact that the apparent pur-

Minn. L. REv. 413. See generally, 15 Fletcher $\$ 7165$; Annot., 87 A.L.R. 597 (1933); Annot., 162 A.L.R. 1237 (1946); Annot., 174 A.L.R. 960 (1948); Lattin, Remedies of Dissenting Stockholders Under Appraisal Statutes, 45 HARv. L. REv. 233 (1931); Lattin, A Reappraisal of Appraisal Stalutes, 38 Mich. L. REv. 1165 (1940); Levy, The Rights of Dissenting Shareholders to Appraisal and Payment, 15 CoRnelL L.Q. 420 (1930); Notes, 38 VA. L. REv. .915, 935 (1952); 60 YALE L.J. 337 (1951).

${ }^{4}$ See Chicago Corp. v. Munds, 12 Del. Ch. 142, 172 Atl. 452 (Ch. 1934), 19 MinN. L. REv. 473; In re Clark's Will, 257 N.Y. 487, 78 N.E. 766 (1931); Adams v. United States Distributing Corp., 184 Va. 134, 34 S.E.2d 244, cert. deried, 327 U.S. 788 (1945); Ballantine $\S 299 ; 15$ Fletcher $\$ 7165$ n. 62; Robinson, Dissenting Shareholders: Their Rights to Dividends and the Valuation of Their Shares, 32 Colum.

L. REv. 60 (1932).

The dissenting shareholder may lose his appraisal rights by laches. National Supply Co. v. Leland Stanford Jr. University, 134 F.2d 689 (gth Cir.), cert. denied, 320 U.S. 773 (1943).

"Weiss v. Atkins, 52 F. Supp. 418 (S.D.N.Y. 1943), rev'd on other grotunds, 149 F.2d 193 (2d Cir. 1945); Wheatley v. A. I. Root Co., 79 Ohio App. 93, 72 N.E.2d 482 (1945); Dickinson v. Fire Ass'n, 378 Pa. 396, 106 A.2d 607 (1954).

${ }^{45}$ De Koven v. Lake Shore \& M.S. Ry., 216 Fed. 955 (S.D.N.Y. 1914).

“Jones v. Missouri-Edison Elec. Co., 199 Fed. 64, aff'd, 203 Fed. 945 (8th Cir. 1913) (holding that the minority can obtain relief where the distribution of stock resulting from the merger is so unjust as to amount to a fraud upon the minority); Hottenstein v. York Ice Mach. Corp., 45 F. Supp. 436 (D. Del. I942), aff'd, 136 F.2d 944 (3d Cir. 1943); Porges v. Vadsco Sales Corp., 27 Del. Ch. 127, 32 A.2d 148 (Ch. 1943); Cole v. National Cash Credit Ass'n, is Del. Ch. 47, 156 Atl. 183 (Ch. 1931) (holding that fraudulent undervaluation or overvaluation of property of one of the corporations in the merger is ground for relief); Armstrong v. Hayden, 126 Misc. 786, 214 N.Y. Supp. 747 (Sup. Ct. 1926); Wick v. Youngstown Sheet \& Tube Co., 46 Ohio App. 253, I88 N.E. 514 (1932).

${ }^{47}$ California's appraisal statute expressly declares that appraisal is the exclusive remedy of the stockholder. CAL. CORP. CODE $\$ 4123$ (West 1955). Other states have accomplished the same result by judicial construction of the statute. Beloff v. Consolidated Edison Co., 300 N.Y. I1, 87 N.E.2d 561 (1949). See also, Hubbard v. Jones \& Laughlin Steel Corp., 42 F. Supp. 432 (W.D. $\mathrm{Pa}_{2}$ 1941); Adams v. United States Distributing Corp., 184 Va. 134, 34 S.E.2d 244, cert. dentied, 327 U.S. 783 (1945). The courts have justified this result by reasoning that the shareholder has only the right to protect his monetary interest and has no right to continue in the business. 
pose of the appraisal statutes is to provide dissenters with a remedy which would not otherwise exist when the majority attempts a prejudicial fundamental corporate change, rather than to deprive them of those remedies which, even in the absence of the appraisal statutes, they would have against irregular, illegal, or fraudulent actions of the majority. ${ }^{48}$

Since the majority interests can easily comply with the terms of state merger statutes, however, the shareholder who wishes to prevent the merger usually must prove what most courts label "fraud," a term which defies uniform definition. While some courts state that they will inquire into the unfairness of a merger agreement if particular circumstances seem to warrant close scrutiny, ${ }^{49}$ others will set aside mergers only when unfairness is so patent as unmistakably to indicate bad faith or reckless indifference to the rights of the minority. ${ }^{50}$ And some cases can be found which base the invalidation of mergers on "constructive fraud." 51 These nebulous phrases seem to require some conduct ap-

${ }^{8}$ Stevens, Private Corporations $\$ 128$, at 591-97 (1949). See also, CraddockTerry Co. v. Powell, i81 Va. 417, 25 S.E.2d 363 (1943); Note, 4 I YALE L.J. 908 (1932).

${ }^{4}$ The fact that the merging corporations were governed by interlocking directors will not necessarily result in upsetting the merger, but such a situation calls for close scrutiny. Bingham v. Savings Investment \& Trust Co., Ior N.J. Eq. 413,138 Atl. 659 (Ch. 1927); Wilson v. Rensselaer \& S. R.R., 184 Misc. 218,52 N.Y.S.2d 847 (Sup. Ct. I 945 ).

to " $[T]$ he unfairness must be of such character and must be so clearly demonstrated as to impel the conclusion that it emanates from acts of bad faith, or a reckless indifference to the rights of others interested, rather than from an honest error of judgment." Porges v. Vadsco Sales Corp., 27 Del. Ch. 127, 133, 32 A.2d 148, 151 (Ch. 1943). See Barrett v. Denver Tramway Corp., 53 F. Supp. 198 (D. Del.), aff'd 146 F.2d 7 or (3d Cir. 1944) ; MacCrone v. American Capital Corp., 5 I F. Supp. 462 (D. Del. 1943); Garrett v. Reid-Cashion Land \& Cattle Co., 34 Ariz. 245, 270 Pac. 1044 (1928); MacFarlane v. North American Cement Corp., 16 Del. Ch. 172, 57 Atl. 396 (Ch. 1928); Outwater v. Public Service Corp., 103 N.J. Eq. 461, 143 Atl. 729 (Ch. 1928).

"The exercise of the statutory power of merger or consolidation is not usually subjected to judicial review on the ground of mere unfairness in valuation. There are, however, some judicial opinions which use general language about fairness and unfairness. . . B But there seems no tendency in the decisions toward adopting any fairness limitation. The courts are reluctant to review relative values in merger or consolidation plans. . . Widest scope is allowed to business discretion and decisions of the majority." Ballantine $\$ 295$, at 692 .

${ }^{81}$ Barrett v. Denver Tramway Corp., 53 F. Supp. 198 (D. Del.), aff'd, I46 F.zd 701 (3d Cir. 1944); Krantman v. Liberty Loan Corp., 52 F. Supp. 705 (N.D. Ill. 1956), aff'd, 246 F.2d 58I (7th Cir. I957) (holding that a merger, which had received the necessary two-thirds vote of the stockholders, would be presumed to be fair and reasonable and could not be successfully attacked by the dissenters unless they could prove actual or constructive fraud); MacCrone v. American Capital Corp., 5 F. Supp. 
proaching fraud, but beyond that they offer very little in the way of concrete guidance in particular cases. There is, moreover, some indication that certain courts, through the stated requirement of fraud, mean to impose a more rigorous burden of proof on the protesting stockholder when a merger is involved than in other cases of corporate squeeze. Thus, while the prevalence of appraisal statutes assures most dissenting shareholders that their shares will be purchased by the corporation if they choose, there remains slight chance under present law that they will successfully resist any effort completely to deprive them of participation in a going business.

\section{SALE OF ASSETS}

The common law rule which required a unanimous stockholder vote for a sale of all the assets ${ }^{52}$ of a going concern ${ }^{53}$ may have given the minority shareholder disproportionate protection. At least from the standpoint of practical business considerations, it is fortunate that this onerous rule has everywhere been superseded by statutes which permit a sale of the corporation's assets upon the approval of a specified majority of the stockholders. $^{\text {5t }}$ These statutes, however, also create an opportunity,

462 (D. Del. 1943); Dratz v. Occidental Hotel Co., 325 Mich. 699, 39 N.W.2d 34I (1949).

${ }^{59}$ A sale of assets was originally intended as a means whereby the corporation might sell all its property for the purpose of liquidation and dissolution, but it has become an important reorganization device, and it is now used in many instances to carry on the business under a different corporate arrangement. See generally, BALLANTINE $\$ 279$; 15 FLETCHER $\S 7216$; Hills, Consolidation of Corporations by Sale of Assets and Distribution of Shares, 19 Calrf. L. Rev. 349 (1931); Comment, 45 Mich. L. Rev. 34 (1947); Note, 58 Colum. L. REv. 251 (1958).

There have been instances in which the courts have set aside a sale of assets when the purpose of the sale was to obtain an end not contemplated by the sale of assets statute. See, e.g., Finch v. Warrior Cement Corp., 16 Del. Ch. 44, 141 Atl. 54 (Ch. 1928) (involving an intended reorganization via a sale of assets).

${ }^{23}$ Des Moines Life \& Annuity Co. v. Midland Ins. Co., 6 F.2d 228 (D. Minn. 1925); Gottschalk v. Avalon Realty Co., 249 Wis. 78, 23 N.W.2d 606 (1946). The reasoning behind this rule was to the effect that ench stockholder had a contractual right to have the corporation continue during its existence the purposes for which it was created. See Des Moines Life \& Annuity Co. v. Midland Ins. Co., sulpra. For criticism of this rule, see BaLLANTINE $§ 281$.

If, however, the corporation was in a failing condition, the common law rule permitted the majority to sell the assets over the objection of the minority. Geddes $v$ : Anaconda Copper Mining Co., 254 U.S. 590 (1921).

"See, e.g., N.Y. Stock CorP. LAW $\$ 21$ (McKinney 1951); OHo REv. Code ANN. \& 8623-72 (Page 1954). See also Solorza v. Park Water Co., 86 Cal. App. 2d 653, 195 P.2d 523 (1948); Garbarino v. Albercan Oil Corp., - Del. Ch. -, rog A.2d 824 (1954). 
similar to that offered by a merger, for the majority unfairly to exercise its power at the expense of the minority. For example, the majority shareholders of corporation $A$, who own shares in corporation $B$, can authorize a sale of all of corporation $A$ 's assets to corporation $B$. In exchange, the stock of corporation $B$ might then be issued to corporation $A$, which subsequently would liquidate by issuing $B$ stock to its stockholders in return for their $A$ shares. ${ }^{55}$ And the unwanted minority stockholder may find to his dismay that the $B$ stock is quite different from his former stock in corporation $A$.

In most states, appraisal statutes are available to dissenters in a saleof-assets situation, too; ${ }^{66}$ and where such statutes are not deemed to afford the exclusive remedy, ${ }^{57}$ the complaining minority may obtain equitable relief if the degree of proof, whatever it is, required to make out a case of fraud ${ }^{\text {b8 }}$ is satisfied.

${ }^{85}$ The corporation can usually sell its assets for shares in the purchasing corporation or for money. In the event that the sale is for shares of stock in the purchaser, however, it has been held that the stockholder cannot be forced to accept the shares of the purchaser in exchange for his shares. Geddes v. Anaconda Copper Mining Co., 254 U.S. 590 (1921); American Seating Co. v. Bullard, 290 Fed. 896 (6th Cir. 1923); Finch v. Warrior Cement Corp., 16 Del. Ch, 44, 141 Atl. 54 (Ch. 1928). Cf. Treadwell v. Salisbury Mfg. Co., 7 Gray (73 Mass.) 393 (1856). An exception to this rule has been recognized where the shares received by the corporation from the purchaser are of such an established market value that they can readily be converted to cash and are thus the equivalent of cash. Geddes v. Anaconda Copper Mining Co., supra $a_{j}$ Ringler v. Atlas Portland Cement Co., 30x Pa. 176, 151 At1. 815 (1930). Cf. Craddock-Terry v. Powell, 181 Va. 417, 25 S.E.2d $36_{3}$ (1943).

${ }^{60}$ See, e.g., N.Y. Stock CoRp. LAW § 2 I (McKinney 195x); OHIo Rev. CODE. ANn. \$ 8623-72 (Page 1954). See also Note, 58 Colum. L. Rrv. $251,253-56$ (1958).

${ }^{57}$ In a few instances the statutes expressly declare that the appraisal rights are exclusive in a sale situation. See Note, 58 Colum. L. REv. 251, 254 \& n. 15 (1958). In other situations, the courts have construed the appraisal statutes as the exclusive remedy of the dissenter is a sale of assets. See, e.g., Beloff v. Consolidated Edison Co., 300 N.Y. Ir 87 N.E.2d 56r (r949). The better rule, however, is that appraisal rights in a sale situation are exclusive only if there are no grounds for the court to impose equitable limitations upon the act of the majority. ${ }_{3}$ FLETCHER $\S 5893$.

${ }^{88}$ See Crawford v. Mexican Petroleum Co., r3o F.2d 359 (2d Cir. x 942); May v. Midwest Refining Co., I21 F.2d 43 I (Ist Cir. 1941); Wechler v. Valley City Mill Co., 93 F. Supp. 444 (W.D. Mich. 1950); Barrett v. Denver Tramway Corp., 53 F. Supp. 198 (D. Del.), aff'd, x46 F.2d 701 (3d Cir. 1944); Starrett Corp. v. Fifth Ave. \& Twenty-Ninth St. Corp., I F. Supp. 868 (S.D.N.Y. 1932); Allaun v. Consolidated Oil Co., 16 Del. Ch. 318,147 Atl. 257 (Ch. 1929); Allied Chem. \& Dye Corp. v. Steel \& Tube Co. of America, 14 Del. Ch. I1, 120 Atl. 486 (x923); Note, 58 Colum. L. REv. 251,256 \& n. 30 (1958).

The fact that there is disagreement over what anounts to fraud is nowhere better illustrated than in the notable opinion of District Judge Leahy in Barrett v. Denver Tramway Corp., supra. 
Certain factors do seem to have received more frequent judicial consideration in sale-of-assets cases. ${ }^{59}$ Proof that the sole motive in making the sale was to eliminate the complaining stockholder from the corporation has been held sufficient to warrant equitable relief. ${ }^{60}$ Although, standing alone, it has not been recognized as a ground for relief, inadequacy of consideration, too, usually has weighed in the dissenter's favor. ${ }^{61}$ Likewise, the fact that the majority owns an interest in the purchasing corporation has received the serious attention of the courts. ${ }^{62}$

\section{ISSUANCE OF STOCK}

The corporate squeeze has been successfully applied through the sale of treasury stock, authorized but unissued stock, or newly authorized stock. The usual technique is to reduce the minority's proportionate

\footnotetext{
${ }^{80}$ See generally, Ballantine $\S 285 ; 13$ Fletcher $\S 5847$; Stevens, Private CORPORATIONS $\$ 126$ (1949).

${ }^{\circ 0}$ See Southern Pac. Co. v. Bogert, 250 U.S. 483 (I919); Welt v. Beachcomber, Inc., I 66 Misc. 29, I N.Y.S2d 177 (Sup. Ct. 1937).

${ }^{a x}$ In a sale of assets the majority owes the minority a duty of seeing that the assets are sold for an adequate price. Kaye v. Kentucky Public Elevator Co., $295 \mathrm{Ky}$. 661,175 S.W.2d 142 (1943). The adequacy of the price received for the assets is a frequent point of contention when the minority seeks to set aside the sale. It has been held that the sale is voidable if it is made for a wholly inadequate consideration, that is, when the consideration is so inadequate as to amount to fraud. Allaun v. Consolidated Oil Co., 16 Del. Ch. 31 8, 147 Atl. 257 (Ch. 1929); Allied Chem. \& Dye Corp. v. Steel \& Tube Co. of America, 14 Del. Ch. 1, 120 Atl. 486 (Ch. 1923).

However, simple inadequacy of price, absent other decisive factors, is not a ground for upsetting the sale upon suit by the minority. See Homer v. Crown Cork \& Seal Co., 155 Md. 66, 14I Atl. 425 (1928); Koehler v. St. Mary's Brewing Co., 228 Pa. 648,77 Atl. 1016 (1910). It has been stated that there is a presumption that the majority will obtain an adequate price for the assets because they will also lose if the price is inadequate. See Note, 58 Colum. L. Rev. 251, 257 \& n. 36 (1958). The reason for the courts' reluctance to inquire into the adequacy of the consideration is said to be the feeling that they are "controlled by the policy of giving directors and majority shareholders a wide business discretion in matters of contract and corporatc management. The courts hesitate to substitute their judgment for that of the parties concerned in matters of business." BaLLANTINE $\$ 285$, at 673. See also 13 FLETCHER $\S 5837$.

For a discussion of the elements of value to be considered in the sale, see generally, 13 FLETCHER $\$ 5899$.

62 "The presumption in favor of the fiduciary fails when, because of the relationship between him and the purchaser, his responsibilities to the corporation might be subordinated to his private interest in the sale. In such situations, the fiduciary, by making a sale for terms inequitable to the vendor, might gain special advantages, and the courts will scrutinize the sale carefully for unfairness." Note, 58 CoLUM. L. REv. 25 I, 258 (1958). See Annot., 24 A.L.R.2d 71 (1952). See also Geddes v. Anaconda Copper Mining Co., 254 U.S. 590 (1921) (where the vendor corporation and purchasing corporation had a common director).
} 
interest in the corporation either by issuing stock at less than fair market value, without offering any of the shares to the minority group, or by issuing stock at a time when the minority is finanically unable to purchase its proportionate part of the issue. By buying large quantities of such stock, the majority can acquire increased voting power in the corporation and, concurrently, can dilute the minority's interest in any corporate surplus. ${ }^{63}$

Prompted by a belief that stockholders should have some measure of protection against the adverse effects of an issuance of additional stock, the courts early developed the theory of pre-emptive rights. ${ }^{64}$ A preemptive right usually entitles its possessor to subscribe to new issues in

${ }^{03}$ See Hyman v. Velsicol, 342 IIl. App. 489 , 97 N.E.2d 122 (1951).
${ }^{01}$ The doctrine of pre-emptive rights is uusually said to have developed from the case of Gray v. Portland Bank, 3 Mass. 363 (1807). See Ross Transport, Inc., v. Crothers, I85 Md. 573, 45 A.2d 267 (1946). See generally, Gibbons v. Mahon, 136 U.S. 549 (1890); Borg v. International Silver Co., II F.2d I47 (2d Cir. 1925); Hammer v. Werner, 239 App. Div. 38,265 N.Y. Supp. 172 (1933). This is said to be a right of which the directors or majority cannot deprive the stockholder. "The directors duty in issuing new shares was to afford to the existing stockholders an opportunity to take the proposed new issue in the proportion in which the shares were held by them. In many cases corporations are incorporated, capitalized and organized by stockholders upon expectations based upon the maintenance of control by the existing majority of the holders of stock. The power of distributing a new issue does not lie at the mere choice of directors. It is not a perquisite which they may use for their private advantage. They may not overthrow or secure for themselves the control of the corporation by means of a new issue of stock." Way v. American Grease Co., 60 N.J. Eq. 263, 269, 47 Atl. 44, 46 (Ch. 1900). The stockholder can waive his preemptive rights, but, with certain exceptions, he cannot be deprived of his right unless he consents. Dunlay v. Avenue M Garage \& Repair Co., 253 N.Y. 274, 170 N.E. 917 (1930); II FLETCHER § 5139 .

It should be noted that, as a practical matter, pre-emptive rights are of slight significance in large public-issue corporations. "The common law doctrine has proved too uncertain when applied to a complex stock structure; and application of the doctrine might hamper legitimate corporate financing." I1 FLETCHER § 5135, at 282. But cf. Venner v. Southern Pac. Co., 279 Fed. 832 (2d Cir. 1922). In the close corporation, however, pre-emptive rights are of the utmost importance to the shareholders if they are to protect their proportionate interest in the corporation. See O'Neal, Close Corporations $\$ \S 4.29,8.09$ (I958); Ballantine, LatTin, \& JenNings, Cases and Materials on Corporations 675 (2d ed. 1953).

Some states regard pre-emptive rights as wholly statutory in nature. See, e.g., Bingham v. Savings Investment \& Trust Co., 102 N.J. Eq. 302, 140 Atl. 321 (Ct. Err. \& App. 1928); Gottlieb v. Heyden Chem. Corp., 33 Del. 82, 90 A.2d 660 (1952). In other states the right does not depend upon any statutory or charter provisions, but is inherent in the ownership of stock. See, e.g., In re McCrory Stores Corp., 34 F. Supp. 739, 743 (S.D.N.Y. 1935); Schramme v. Cowin, 205 App. Div. 20, 199 N.Y. Supp. 98 (1923). Charter provisions sometimes regulate the right. See, e.g., Cal. CORP. CODE § I 106 (West. 1955). 
proportion to his existing holding of outstanding stock in the corporation, ${ }^{60}$. and the fact that these rights normally do not apply to nonvoting stock indicates that their primary purpose is to protect the shareholder's voice in the corporate management. ${ }^{66}$

For a variety of reasons, many states have engrafted limitations on the pre-emptive rights doctrine. ${ }^{07}$ In some states, the corporate charter determines whether and to what extent stockholders may enjoy preemptive rights. ${ }^{68}$ Furthermore, although these rights may exist, the majority sometimes has the power to eliminate them by charter amendment. ${ }^{69}$ Thus, it becomes important to determine when pre-emptive rights exist, for to the extent that they are restricted, the chances of a successful squeeze increase. ${ }^{70}$.

Even where pre-emptive rights are relatively unimpaired by statute, however, several exceptions have sliced into the protection they afford. First, it is usually held that no pre-emptive rights attach to stock issued in exchange for property. ${ }^{71}$ This exception is obviously necessary, for desirable property is frequently obtainable only in exchange for a bloc of the acquiring corporition's stock. However, it would seem sensible to limit the exception to situations in which exercise of the pre-emptive right would unduly impede the fulfillment of transactions undertaken for legitimate business reasons.

${ }^{{ }^{65}}$ See Thom v. Baltimore Trust Co., $158 \mathrm{Md} .352,148$ Atl. 234 (1930), 39 YALE L.J. 905 ; Steven v. Hale-Haas Corp., 249 Wis. 205,23 N.W.2d 620 (1946); Hammer v. Cash, 172 Wis. 185,178 N.W. 465 (1920); II FletcheR $\$ 5135$ at $285 \&$ n. 46.

${ }^{\circ 0}$ See Yoakam v. Providence Biltmore Hotel Co., 34 F.2d 533 (D.R.I. r 929), Frey, Shareholder' Pre-emptive Rights, 38 YALE L.J. 563 (1929). But it has occasionally been held that the right extends to preferred stock. See Tennant v. Epstein, 27 I Ill. App. 204, reo'd on other grounds, 356 III. 26,189 N.E. 864 (1934). See also BallantinE $\$ 209$.

${ }^{67}$ It has been pointed out that the doctrine is becoming more limited because it is not adaptable to the complex corporate stock structures of today, esepcially in corporations with numerous classes of stock. See Drinker, The Pre-Emptive Right of Shareholders to Subscribe to New Shares, 43 HARv. L. REv. 586, 605 (1930); Frey, Shareholders' Pre-Emptive Rights, 38 YALE L.J. 563 (1929).

${ }^{68}$ See, e.g., Cal. Corp. COde \& 1106 (West 1955); N.Y. Stock Corp. Law \& 39 (McKinney 1951); Ohio Rev. Code ANN. § r 7or.15 (Page 1954); OKIA. Stat. ANN. tit. 18, § 1.45 (perm. ed. 1953); WIs. STAT. \$ 180.21 (1955).

${ }^{60}$ See, e.g., Milwaukee Sanitarium v. Swift, 238 Wis. 628, 300 N.W. 760 (194I).

${ }^{70}$ See, e.g., Ohro Rev. Code ANN. $\$ 8623-35$ (d) (Page 1954).

${ }^{71}$ One of the leading cases in Thom v. Baltimore Trust Co., $158 \mathrm{Md} .352,148$ Atl. 234 (1930), 39 YALE L.J. 905 (1929), where the court reasoned that the pre-emptive right existed only if it could be exercised consistently with the object which the stock issue was designed to accomplish. See also Meredith v. New Jersey Zinc \& Iron Co., 55 N.J. Eq. 211,37 Atl. 539 (Ch. 1897). This exception has been severely criticized. Frey, Shareholders' Pre-Emptive Rights, 38 YALE L.J. 563, 579 (1929). 
Secondly, pre-emptive rights generally do not attach to originally authorized but unissued stock. ${ }^{\tau^{2}}$ The reasoning here is that stockholders understand that the corporation is free to issue all authorized shares before pre-emptive rights become operative. ${ }^{73}$ But there is an exception to the exception, in that pre-emptive rights will attach where the purpose of the issue is expansion of the business. ${ }^{74}$ If, however, the stock is issued to secure capital to carry on the normal business operations, no pre-emptive right exists. ${ }^{75}$ One qualification of particular help to minority stockholders is that authorized but unissued stock cannot be issued by the directors to themselves in order to gain or perpetuate con. trol. ${ }^{76}$

There is also authority to the effect that no pre-emptive rights attach to the issuance of treasury stock. ${ }^{77}$ The exception is grounded in the notion that the issuance of such re-acquired stock does not reduce the stockholder's original proportionate interest in the business. ${ }^{78}$ However, such a viewpoint disregards the fact that an issuance of treasury stock may impair the stockholder's newly acquired position, a result especially unjustifiable if the stockholder purchased his interest after redemption and before re-issuance of the stock. A more serious criticism of this particular exception is that it offers yet another method for freezing out minority stockholders through redemption of the shares of some stockholders and re-issuance to the majority, thereby increasing the control margin of the latter group. ${ }^{79}$

\footnotetext{
${ }^{72}$ Yasik v. Wachtel, 25 Del. Ch. 247, 77 A.2d 309 (Ch. I 94I), 40 MrCH. L. REv. I15 (I94I); Ross Transport, Inc. v. Crothers, 185 Md. 573, 45 A.2d 267 (1946); Dunlay v. Avenue $M$ Garage \& Repair Co., 253 N.Y. 274, 170 N.E. 917 (1930).

${ }^{73}$ Ross Transport, Inc. v. Crothers and Dunlay v. Avenue M Garage \& Repair Co., supra note 72. See also, Drinker, The Pre-Entptive Right of Shareholders to Susbcribe to New Shares, 43 HARv. L. REv. 586 (1930).

" See Yasik v. Wachtel, 25 Del. Ch. 247, 17 A.2d 309 (Ch. 1941), $40 \mathrm{Mrch}$. L. REv. 115; Essex v. Essex, 14I Mich. 200, 104 N.W. 622 (1905); Dunlay v. Avenue M Garage \& Repair Co., 253 N.Y. 274, 170 N.E. 917 (1930).

${ }^{75}$ See cases cited at note 74 supra.

${ }^{30}$ Schwab v. Schwab-Wilson Mach. Co., 13 Cal. App. 2d 1, 55 P.2d 1268 (1936); Canada Southern Oils, Ltd. v. Manabi Exploration Co., 33 Del. Ch. 537, 96 A.2d 8 ro (Ch. 1953).

${ }^{27}$ Borg v. International Silver Co., II F.2d 147 (2d Cir. I925).

${ }^{78}$ Fletcher reasons that the exception is based on practical grounds of convenience in that treasury shares "are usually sold from time to time and are not reissued in large amounts." II FLETCHER $\S 5136.2$ at 297-98. Crosby v. Stratton, 17 Colo. App. 212, 68 Pac. 130 (1902).

${ }^{70}$ Dunn v. Acme Auto \& Garage Co., 168 Wis. 128, 169 N.W. 297 (1918). In Runswick v. Floor, II6 Utah 91, 208 P.2d 948 (1949), abont I,000,000 shares were outstanding when 150,000 treasury shares were issued to a director, who was a
} 
Finally, pre-emptive rights are not recognized in favor of holders of bonds which can be converted into voting stock until such bonds are actually converted. ${ }^{80}$ Generally, neither shares having potential voting rights, such as preferred shares which obtain voting privileges only after a period of default in dividends, ${ }^{81}$ nor shares which are soon to lose their voting incidents can claim pre-emptive rights. ${ }^{82}$

Although the judicial and legislative restrictions upon the doctrine of pre-emptive rights may have reasonable justification in terms of corporate policy, it is evident that they make it less difficult to squeeze the minority group. If the minority stockholder has no pre-emptive right, or is financially unable to exercise his right, he must seek judicial enforcement of the fiduciary obligations of the directors and majority stockholders and, ultimately confront all of the attendant difficulties of proof. ${ }^{83}$

\section{Stock Dividends}

Majority interests can sometimes increase their measure of control by paying a dividend in stock of another class to their own class of stock. $^{84}$ For example, if the majority stockholders wished to dilute the interest or reduce the voting strength of holders of, say, class $B$ common stock, and if there were a substantial number of authorized but unissued shares of class $B$ common stock, the majority could declare a dividend in class $B$ common stock on their own stock. ${ }^{85}$ Confronted with such a course of action, the original holders of class $B$ common stock might deem it wiser to sell their stock than to remain and suffer further dilution.

Most states authorize dividends to one class of stock paid in shares of another class, and in those states where such a dividend is not expressly recognized, a provision in the corporate charter can often supply

member of the group controlling the corporation at the time. The court held that the stockholders had no pre-emptive right in the treasury stock.

${ }^{80}$ Van Slyke v. Norris, 159 Minn. 63, 198 N.W. 409 (1924).

${ }^{81}$ See Yoakam v. Providence Biltmore Hotel Co., 34 F.2d 533 (D. R.I. 1929) (dictum).

${ }^{88}$ See Frey, Shareholders Pre-emptive Rights, 38 YALE L.J. 563, 578 (1929).

${ }^{88}$ See Ballatine $\S 209$; Annot., 138 A.L.R. 526 (1942).

${ }^{84}$ Cf. Bodell v. General Gas \& Elec. Corp., 15 Del. Ch. 119, 132, Atl. 442 (Ch. 1926).

${ }^{85}$ Ballantine criticizes the power of directors in some states to declare a dividend on common stock in the preferred shares. He argues that such a dividend has the effect of prejudicing the relative rights of the shareholders. Ballantine $\S 208(\mathrm{~b})$. See Rowell, Rights of Preferred Shareholders in Excess of Preference, 19 MinN. L. REv. 406, 410 (1935). 
validation. ${ }^{86}$ Only a few states, such as North Carolina, afford the protection of requiring that the directors obtain annual authorization for a stock dividend from the class adversely affected. ${ }^{87}$ In the absence of such a safeguard, however, the minority stockholder must, again, attempt to establish a violation of the majority's fiduciary obligation in order to prevent the declaration of a stock dividend. And the difficulty inherent in proving a sole purpose to squeeze out the minority is compounded here by the discretion accorded directors in declaring dividends ${ }^{88}$ and by the customary reluctance of the courts to interfere in management affairs. $^{89}$

\section{BANKRUPTCY}

Another unique freeze-out device is the filing of a voluntary petition in bankruptcy with the intent of outbidding the minority interests at the bankruptcy sale. An excellent illustration of the use of this tactic is afforded in Porterfield v. Gerstel, ${ }^{90}$ where the majority directors were alleged to have committed acts, within a month after securing control, designed to give a prospering corporation the appearance of inability to meet its obligations. The alleged purpose of this strategem was to bring about a bankruptcy sale at which the majority could purchase the corporate assets, thereby eliminating the minority from the corporation. On appeal, it was held that bankruptcy proceedings could not be used to perpetrate a fraud upon the minority.

The minority stockholders' success in preventing the carrying out of such a scheme will ultimately depend, then, upon their ability to prove that the voluntary petition was filed in a fraudulent attempt either to oust them from the corporation or otherwise unduly to prejudice their interests. Significant in situations of this type would be evidence showing whether the corporation's assets exceeded its liabilities, whether the corporation could meet its obligations as they came due, whether creditors were pressing for payment of their debts at the time of the filing of the bankruptcy petition, the past relationship between majority

\footnotetext{
${ }^{80}$ See, e.g., Ohio Rev. Code ANN. $§$ 1701.33 (Page Supp. I958); VA. Code ANN. § 13.1-43 (1956); WIs. STAT. § I 80.38 (I955).

${ }^{87}$ N.C. GEN. STAT. $§ 55-5$ I (Supp. 1957).

${ }^{88}$ See Schell v. Alston Mfg. Co., 149 Fed. 439 (N.D. Ill. 1906); Williams v. Western Union Tel. Co., 93 N.Y. 162 (1883). Their action will not be interfered with so long as they have acted in good faith. Schmitt v. Eagle Roller Mill Co., 199 Minn. 382, 272 N.W. 277 (1937).

${ }^{80}$ See Connelly v. Weisfield, 142 N.J. Eq. 406, 59 A.2d 869 (Ct. Err. \& App. 1948).

${ }^{D 0} 222$ F.2d 137 (5th Cir. 1955).
} 
and minority, and any acts of mismanagement which the majority directors may have committed.

\section{Charter Amendments}

Since the Dartmouth College case, ${ }^{91}$ the shareholder's interest has traditionally been considered contractual in nature, and the rights, privileges, and responsibilities conferred upon the shareholder by this contract determine, to a great extent, the value of the stockholder's interest in the corporation. Thus, the majority can often achieve a desired end by altering the terms of this contract.

The most obvious device for increasing the worth of one class of stock at the expense of another is amendment of the dividend provision of the share contract. Although in some jurisdictions it is questionable whether accrued dividends can be eliminated without consent, ${ }^{02}$ future dividend rights generally can be altered downward. ${ }^{93}$ Thus, future dividend rates can be lowered and cumulative shares can be made noncumulative $e^{94}$ by any group controlling enough votes to amend the charter.

A significant element of the shareholder's contract is the voting right which he originally acquires. Although the elimination or alteration of voting incidents is not permitted in many states, some jurisdictions have upheld charter amendments which abrogate cumulative voting rights, ${ }^{95}$ eliminate the right of preferred stock to vote when dividend payments

${ }^{91}$ Dartmouth College v. Woodward, 17 U.S. (4 Wheat.) 518 (1819).

${ }^{02}$ In Consolidated Film Industries v. Johnson, 22 Del. Ch. 262, 197 Atl. 489 (Ch. 1937), the defendant corporation adopted an amendment to its certificate of incorporation which provided that existing preferred stock, on which there were accrued and unpaid dividends, were to be exchanged for preferred stock entitled to a lower dividend rate. It was held that the corporation could not force the stockholder to forfeit his rights to accrued dividends. The court pointed out that the corporation had the power to change the character of his stock; but he did not take it with notice that the corporation could cancel his right to accrued dividends. See also Morris v. American Public Utilities Co., 14 Del. Ch. 136, 122 Atl. 696 (Ch. 1923); Wheatley v. A. I. Root Co., 147 Ohio St. 127, 69 N.E.2d 187 (1946); Note, 32 CORNELL L.Q. 586 (1947); Note, 18 U. CinN. L. REv. 172 (1949). Some states have statutes which expressly authorize the elimination of accrued dividends by charter amendment. See, e.g., Ohio REv. CODE ANN. \$ 7 701.17(i) (Page 1954).

${ }^{93}$ In Davis v. Louisville Gas \& Elec. Co., 16 Del. Ch. 157, 142 Alt. 654 (Ch. 1928), the charter amendment decreased the future dividend rate. The court held that this was permissible under the reserved power. See Ballantine, LatTin \& Jennings, Cases and Materials on Corporations 98 I (2d ed. 1953).

${ }^{93}$ See Yoakam v. Providence Biltmore Hotel Co., 34 F.2d 533 (D. R.I. 1929).

${ }^{95}$ See Maddock v. Vorclone Corp., I7 Del. Ch. 39, 147 Atl. 255 (Ch. 1929). But see Loewenthal v. Rubber Reclaiming Co., 52 N.J. Eq. 440, 28 Atl. 454 (Ch. 1894). 
are in arrears, ${ }^{96}$ or transfer voting rights from common to preferred stock. .87

Similarly, charter amendments have been upheld which made nonredeemable shares redeemable, ${ }^{98}$ altered or abolished pre-emptive rights, ${ }^{92}$ or made nonassessable shares assessable. ${ }^{100}$ Any of these techniques could be effectively employed adversely to affect minority interests.

Another efficient device is the creation, through charter amendment, of a class of prior preferred stock, coupled with an option in the holders of the original preferred stock to exchange their old shares for the new ones. ${ }^{101}$ The preferred stockholders will probably be reluctant to forego the dividend priority of the new preferred shares, although valuable incidents of the old shares will be lost in the exchange.

While it is evident that the possibilities for use of charter amendments to harrass minority interests are numerous, the minority stockholder is not helpless when faced with an unfavorable amendment. $\mathrm{He}$ may yet block the amendment if he can show that the proposed change cannot be made under the terms of the share contract, that the statute authorizing the amendment is unconstitutional, or that the ma-

${ }^{\text {De }}$ See Yoakam v. Providence Biltmore Hotel Co., 34 F.2d 533 (D. R.I. 1929).

${ }^{87}$ See Topkis v. Delaware Hardware Co., 23 Del. Ch. 125, 2 A.2d 114 (Ch. 1938).

For representative statutes dealing with the subject of alteration of voting rights by charter amendment, see CAL. CORP. CODE $\$ 3634$ (West 1955); N.Y. STOCK CORP. LAw \& 35 (McKinney I95I). See also Note, 54 HaRv. L. REV. I368 (194I).

${ }^{98}$ In Cowan v. Salt Lake Hardware Co., II 8 Utah 300, 22 I P.2d 625 (1950), the court sustained a charter amendment making non-redeemable shares redeemable. However, one factor weighing heavily in this case was the fact that the charter would expire in 5 months, which the court used to counter allegations of unfairness. Cf. Beloff $v$. Consolidated Edison Co., 300 N.Y. Ix, 87 N.E.2d 561 (1949). But in Breslav v. New York \& Queens Elec. Light \& Power Co., 249 App. Div. 18I, 29 I N.Y. Supp. 932 (1936), aff'd, 273 N.Y. 593, 7 N.E.2d 708 (1937), the court held that the corporation could not convert nonredeemable shares to redeemable shares under statutory authority to "classify and reclassify" the shares of the corporation. See also Outwater v. Public Service Corp., 103 N.J. Eq. 46I, I43 Atl. 729 (Ch. I928), aff'd, I04 N.J. Eq. 490, 146 Atl. 916 (Ct. Err. \& App. I929).

${ }^{\circ 9}$ See, e.g., Gottlieb v. Heyden Chem. Corp., 90 A.2d 660 (Sup. Ct. Del. 1952); Milwaukee Sanitarium v. Swift, 238 Wis. 628,300 N.W. 760 (1941). New York expressly authorizes the elimination of pre-emptive rights by charter amendment. N.Y. STOCK CORP. LaW \$ 35 (McKinney 195 I).

${ }^{100}$ Someville v. St. Louis Mining \& Milling Co., 46 Mont. 268, 127 Pac. 464 (1912).

${ }^{101}$ See Barrett v. Denver Tramway Corp., 53 F. Supp. I98 (D. Del. I943), aff'd, 146 F.2d 70I (3d Cir. 1944); Shanik v. White Sewing Machine Corp., 25 Del. Ch. 37I, ig A.2d 831 (Ch. 1941); Johnson v. Lamprecht, I33 Ohio St. 567, I5 N.E.2d $127(1938)$. 
jority has violated its fiduciary duty to the minority. ${ }^{102}$ A few states also give stockholders the protection of appraisal statutes if certain fundamentally prejudicial charter amendments are adopted in spite of their objections. ${ }^{103}$

It is seldom easy, however, to determine precisely what the share contract provides, for it normally encompasses the corporate charter and by-laws as well as certain mandatory statutory provisions ${ }^{104}$ imposed by state of incorporation. Upon establishing the various elements of the share contract, the stockholder may challenge a proposed amendment not only on the ground that there is no authority in the contract for such an amendment, but also on the ground that all of the formalities required by the contract for passage of an amendment have not been observed, or that the amendment in question is prohibited by a specific provision in the contract.

The constitutionality of a charter amendment is usually challenged when it was authorized by a statute enacted subsequent to the date on which the corporation was chartered. ${ }^{105}$ Such statutes are upheld only if they are within the purview of a state's reserved power clause, a constitutional proviso retaining for the state the power statutorily to alter or repeal charters of domestic corporations. ${ }^{108}$ Arguments that certain types of legislation cannot be applied retroactively to existing corporations are traditionally based on the contract and due process clauses of the federal and state constitutions. Thus, it is urged that under the contract clause, the reserved power can permit alterations only in cases involving a public interest sufficient to justify action under the state's police power. ${ }^{107} \mathrm{~A}$ due process argument may be made to the effect

\footnotetext{
${ }^{102}$ In discussing the protection of the minority in charter amendment situations, Ballantine has said: "All powers granted to a corporation and its directors and majority shareholders are impliedly to be exercised ... only in good faith and for legitimate purposes." BALLANTiNe $\S 278$ at 655 , citing Small v. Sullivan, 245 N.Y. 343,157 N.E. 261 (1927).

${ }^{103}$ See Ballantine, Lattin \& Jennings, Cases and Materials on CorporaTIONS ro22 n. 2 (2d ed. 1953).

${ }^{104}$ In order to be considered a part of the share contract of each domestic corporation, a statute must be mandatory. That is, it must be felt that the statute was enacted for the protection of the public or classes of persons in the corporation that the legislature believes need special protection.

${ }^{105}$ See Wilson v. Cherokee Drift Mining Co., $1_{4}$ Cal. 2d 56, 92 P.2d 802 (1939);

Beloff v. Consolidated Edison Co., 300 N.Y. Ir, 87 N.E.2d 56r (1949); Harbine v. Dayton Malleable Iron Co., 6r Ohio App. r, 22 N.E.2d 281 (1939).

${ }^{100}$ See Ballantine, $\$ \S 275-76$.

${ }^{107}$ See Yoakam v. Providence Biltmore Hotel Co., 34 F.2d 533 (D. R.I. 1929); Zabriskie v. Hackensack \& N.Y.R.R., 18 N.J. Eq. 178 (1867); Yukon Mill \& Grain
} 
that reserved power clauses do not permit the destruction of property rights of stockholders which are "vested." 108 Both of these theories are currently receiving scant judicial attention, at least in the more important commercial states, the present tendency of the courts being to construe reserved power clauses liberally, so as to allow greater legislative freedom in the application of statutes to previously chartered corporations. ${ }^{109}$

Should none of the above remedies be available or prove feasible, the dissenter may successfully bring an action in equity to enjoin treatment he considers unfair. ${ }^{110}$ But, as in the situations previously discussed, courts exhibit their varied dispositions toward granting equitable relief in the different tests and degrees of proof which they require in particular cases: For example, cases involving impairment of the minority's right to vote are occasionally treated differently than cases involving other types of charter amendments, since some courts will not consider the unfariness of a voting amendment in the absence of fraud. ${ }^{111}$

\section{Conclusion}

The methods available to majority interests to take advantage of minority stockholders are so numerous and so effective that there is often little a stockholder can do, especially in a close corporation, adequately to protect himself. Any solution to this problem must avoid the pitfall of imposing major limitations on the control group in a close corporation, lest the substantial powers necessary for effective operation of a business be unduly hampered. It should also be recognized that, in many instances, the stockholder's miseries are compounded because he fails to utilize effectively the remedies which are available to him, rather than because remedies do not exist. An alert stockholder, acting under the advice of counsel, can often, by careful preservation of evidence and intelligent reliance on recognized legal and equitable remedies, do a

Co. v. Vose, 201 Okla. 376, 206 P.2d 206 (1949); Garey v. St. Joe Mining Co., 32 Utah 497, 91 Pac. 369 (1907); State ex rel. Swanson v. Perham, 30 Wash. 2d 368, 191 P.2d 689 (1948).

${ }^{108}$ See Consolidated Film Indust., Inc. v. Johnson, 22 Del. Ch. 40 I, I 97 Atl. 489 (Ch. 1937); Keller v. Wilson \& Co., 21 Del. Ch. 391, 190 Atl. 115 (Ch. 1936); In re Mt. Sinai Hospital, 250 N.Y. 103, I64 N.E. 87 I (1928); Roberts v. Robert Wicks Co., 184 N.Y. 257, 77 N.E. $1_{3}$ (I906).

${ }^{100}$ See Davis Louisville Gas \& Elec. Co., I6 Del. Ch. 157, 142 Atl. 654 (Ch. 1928); McNulty v. W.8J. Sloane, 184 Misc. 835, 54 N.Y.S.2d 253 (Sup. Ct. I946); Note, 37 CoRnelL L.Q. $768,772 \&$ n. 24 (1952).

${ }^{110}$ See note 104 supra.

${ }^{111}$ See Maddock v. Vorclone Corp., 17 Del. Ch. 39, 147 Atl. 255 (Ch. 1929). 
great deal toward protecting himself. Nevertheless, there are a number of reasonable statutory changes which could profitably be made in many states to afford the minority stockholder in a close corporation more adequate protection.

I. Perhaps the most helpful contribution in this area of the law would be a stautory modification of the tests now employed by the courts in deciding whether to grant equitable relief. By requiring only a showing of unfairness under all the circumstances in all instances of minority challenge to majority action, relief would be more readily obtainable than is presently the case in those situations where some sort of fraud must be proved. ${ }^{112}$ In addition, much of the present confusion occasioned by the interchanging of inherently vague standards could be eliminated by uniform statutory acceptance of the criterion of unfairness. A statute adequate to satisfy most cases might declare that, provided the complaining stockholder can establish substantial detriment, unfairness would exist when either (a) there is no legitimate business reason for the action instigated by the majority; (b) the same legitimate business objective could be attained by an alternate plan under which the minority would not be unduly prejudiced; or (c) the asserted business objective is clearly secondary in importance to the majority's purpose of improving its position at the minority's expense. With the exception of item (b), these suggestions involve questions which most courts customarily consider, and it is difficult to see how item (b) could have any harmful effect on the efficient operation of a corporation.

2. In any situation in which a minority shareholder's position in the corporation is substantially impaired-whether as a result of a merger, sale of assets, charter amendment, or kindred device-it would seem desirable to allow the stockholder to have his shares appraised and purchased by the corporation at a fair value. This could be accomplished by redrafting the appraisal statutes concerned so as to emphasize the substantial effect of corporate acts on the stockholder, instead of conditioning appraisal on the form a squeeze play takes. Thus, rather than granting appraisal as a matter of course in named types of fundamental changes, the statute would allow appraisal upon proof that any action taken by the corporation has eliminated valuable rights of the stockholder or has resulted in a decrease in the value of his shares. ${ }^{1.13}$

\footnotetext{
${ }^{112}$ The "fairness" test has been urged by several writers. See, e.g., Latty, Fairness -The Focal Point in Preferred Stock Arrearage Elimination, 29 VA. L. Rev. I (1942); Dodd, Fair and Equitable Recapitalization, 55 HARv. L. REv. 780, 791 (1942).

${ }^{113}$ Appraisal rights are usually granted automatically to a dissenting stockholder in the case of a fundamental change such as a merger. It has been suggested, however,
} 
In order to insure that this remedy is not overlooked by an affected stockholder, the corporation should also be required to notify the stockholders of their appraisal rights whenever a change is proposed which might give rise to these rights. ${ }^{114}$

3. By adopting a provision similar to section 55-50(i) of the new North Carolina Business Corporation Act, ${ }^{115}$ which requires a corporation to pay one-third of its annual net profits in dividends upon written demand of twenty per cent of its stockholders, other states could provide better protection against excessive dividend withholding.

4. A statutory requirement that all corporations elect their directors by cumulative voting would help minority interests to gain a voice on the board of directors in corporations where this would not otherwise be possible. ${ }^{116}$ The presence of a minority shareholder on the board would probably make the majority group somewhat more reluctant to serve selfish ends and would also enable the minority to stay better informed, so that it might protect its interests more intelligently.

5. Finally, it would seem desirable to follow the lead of at least one state, which has attempted to prevent the recurrence of cases such as Federal United Corporation v. Havender ${ }^{117}$ by making it unlawful to avoid the statutory restrictions on charter amendments through the expedient of the merger technique. ${ }^{118}$

that appraisal rights are often granted unnecessarily. "[R]econsideration might indicate that appraisal rights should be made to turn less on the shareholder finding himself in a different legal entity or in an expanded enterprise than on being drastically changed with respect to participation in earnings, liquidation and control. It might also indicate that appraisal rights in a sale of assets situation should be granted, and only in, a sale of assets for securities of the purchaser corporation ... rather than be denied in all sales, as is the case in most jurisdictions, or be granted even in sales for cash, as appears to be the case in some others." Latty, Some Miscellaneous Novelties in the New Corporation Statutes, 23 LAW \& CONTEMP. PrOB. 363, 390 (1958), citing with approval a I 953 provision in the New York law denying appraisal rights to shareholders of the surviving corporaiton in a consolidation when the consolidation does not make such fundamental changes in the dissenter's share contract as would warrant appraisal rights in the event of a charter amendment.

${ }^{116}$ The North Carolina Business Corporation Act requires that shareholders must be notified of their appraisal rights when they are asked to vote on cetain fundamental changes. N.C. GEN. STAT. $\$ \S 55-100,55-108,55-112,55-1 \times 8$ (Supp. 1957). See also, PA. STAT. ANN. tit. 15, \$\$ 2852-311, 2852-902 (Supp. 1957).

${ }^{116}$ N.C. GEN STAT. \& 55-50(i) (Supp. 1957).

${ }^{116}$ For a representative statute which requires that shareholders be allowed to cumulate their votes, see CAI. CORP. CODE $§ 2235$ (West 1955).

${ }^{117}$ See text at note ${ }_{3} 8$ supra.

${ }^{118}$ N.C. GeN. STAT. $\$ 55^{-108(b) ~(S u p p . ~ I 957) . ~ S e e ~ L a t t y, ~ s u p r a ~ n o t e ~ I I 5, ~ a t ~}$ $387 \&$ n. 161 . 